\title{
Free Mycolic Acids as Criteria in the Classification of Gordona and the 'rhodochrous' Complex
}

\author{
By L. ALSHAMAONY AND M. GOODFELLOW \\ Department of Microbiology, The University, Newcastle upon Tyne $N E_{1}{ }_{7} R U$ \\ AND D. E. MINNIKIN \\ Department of Organic Chemistry, The University, \\ Newcastle upon Tyne NEI $7 R U$ \\ AND HALINA MORDARSKA \\ Institute of Immunology and Experimental Therapy, \\ Polish Academy of Sciences, Wroctaw, Poland \\ (Received I4 April 1975; revised 28 June 1975)

\begin{abstract}
SUMMARY
The methyl esters of free mycolic acids from representative strains of Gordona bronchialis, G. rubra, G. terrae and Nocardia kirovani each gave, on mass spectroscopy, homologous series of anhydromycolic esters containing from one to four double bonds with the main components of the parent mycolic acids centred on $56,58,62$ or 64 carbon atoms (total range from $C_{52}$ to $C_{66}$ ). The mycolic acids from the Gordona strains, with chain lengths centred around $\mathrm{C}_{60}$, form a group intermediate in size between nocardomycolic acids (centred around $\mathrm{C}_{50}$ ) and mycolic acids sensu stricto (centred around $\mathrm{C}_{70}$ to $\mathrm{C}_{90}$ ); these are different from those of the 'rhodochrous' complex which have anhydromycolates ranging from $\mathrm{C}_{34}$ to $\mathrm{C}_{50}$. Gordonae are thus more closely related in their mycolic acid composition to Nocardia than to Mycobacterium but can be distinguished from each of these genera.
\end{abstract}

\section{INTRODUCTION}

The genus Gordona (Tsukamura, 1971) was proposed for a group of slightly acid-fast bacteria isolated from sputa of patients with pulmonary disease and also from soil. The isolates, classified as Gordona bronchialis, G. rubra and G. terrae, were readily differentiated from nocardiae and mycobacteria but were difficult to distinguish from rhodochrous strains. The data accumulated so far indicate that rhodochrous strains form a recognizable, but heterogeneous, taxon equivalent in rank to the genera Nocardia and Mycobacterium (Cross \& Goodfellow, 1973; Alshamaony, Goodfellow \& Minnikin, 1976; Goodfellow et al. 1974). The relationship between the genus Gordona and the 'rhodochrous' complex, however, remains unsettled though Tsukamura (1973, 1974) has proposed that gordonae and rhodochrous strains be classified in a single genus with three new species, Gordona rhodochroa, G. rosea and G. rubropertincta (syn. G. rubra), erected for strains previously classified in the 'rhodochrous' complex.

Nocardiae, mycobacteria and true corynebacteria can be distinguished from one another by analysis of their respective mycolic acid moieties (Lechevalier, Horan \& Lechevalier, 1971; Lechevalier, Lechevalier \& Horan, 1973). The mycolic acids of the rhodochrous cluster (Goodfellow, 197I) have significantly lower molecular weights than those from true nocardiae (Minnikin, Patel \& Goodfellow, 1974; Alshamaony et al. 1976). Similar lipid 
Table I. Designation and sources* of test strains

N654 Gordona bronchialis, NCTC10667; M. Tsukamura, 3410; H. Kondo. ATCC25592. Sputum, pulmonary lesion. Type strain

N66I G. bronchialis, strain T2, M. Tsukamura, 341 I. Sputum, pulmonary lesion

N655 G. rubra, NCTC10668; M Tsukamura, 3605. ATCC25593. Soil

N657 G. rubra, strain T3; M. Tsukamura, 3605. Soil

N658 G. rubra, strain T4; M. Tsukamura, 3606. Soil

N656 G. terrae, NCTC10669; M. Tsukamura, 3612. ATCC25594. Soil

N659 G. terrae, strain T5; M. Tsukamura, 3612. Soil

N662 G. terrae, strain T6; M. Tsukamura, 3613. Soil

N647 Nocardia kirovani, G. Michel, Universite Claude Bernard, Villeurbanne, France, IMI 374

* ATcc, American Type Culture Collection, Rockville, Maryland, U.S.A.; NCTC, National Collection of Type Cultures, London; N, Laboratory number.

analyses of Gordona strains might clarify their relationship with rhodochrous strains, nocardiae and mycobacteria. This report presents results of the mass spectral analysis of methyl esters of free mycolic acids from representative strains of Gordona bronchialis, G. rubra and G. terrae, and from a strain of Nocardia kirovani.

\section{METHODS}

Strains and growth conditions. Details of the cultures examined are given in Table I. All the strains were maintained on yeast extract agar slopes at room temperature.

The test strains were grown in shake culture at $37^{\circ} \mathrm{C}$ for 3 to 5 days in modified Sauton's medium (Mordarska, Mordarski \& Goodfellow, 1972) amended with vitamin $B_{1}(50 \mathrm{mg} / \mathrm{l})$. Cultures were checked for purity at maximum growth, killed by shaking with formalin ( $\%$, v/v), separated by centrifuging, washed with distilled water and freeze-dried.

Preparation of methyl esters of free mycolic acids and their mass spectroscopy. The free mycolic acids were isolated, purified, esterified and then examined by mass spectroscopy as described by Alshamaony et al. (1976). Partial mass spectra of the methyl esters of the free mycolic acids of all the strains listed in Table I have been deposited with the British Lending Library as Supplementary Publication No. SUP 28004 (9 pages); for details of how to obtain copies, see Alshamaony et al. (1976); price 25p per copy (65p to Europe, $75 \mathrm{p}$ elsewhere).

\section{RESULTS}

Methyl esters of mycolic acids from Gordona strains and $N$. kirovani fragment on mass spectrometry in the same way as those of nocardiae (Maurice, Vacheron \& Michel, 197I); the process is described in the accompanying paper (Alshamaony et al. 1976). The main peaks in the mass spectra of the methyl esters of the free mycolic acids from these strains correspond to fragments associated with the long alkyl branch in the 2-position (Table 2), anhydromycolates (Table 3), and aldehydes which, as noted in the accompanying paper, are variable in intensity.

\section{DISCUSSION}

Numerical taxonomic data indicate that Gordona has a closer affinity to the genus Nocardia than to the genus Mycobacterium, but shows an even greater similarity to the 'rhodochrous' complex from which it cannot be readily separated. However, using in vitro antimicrobial sensitivity tests, Goodfellow \& Orchard (1974) distinguished between gordonae (which were resistant to rifampicin) and rhodochrous strains (which were all inhibited by this antibiotic). 
Table 2. Peaks in the mass spectra of methyl mycolates of gordonae and N. kirovani corresponding to fragments derived from the 2-branched 3-hydroxyester unit

The main component of each series is denoted by +++ , any component greater than $50 \%$ of the main peak by ++ and all other significant components by + .

\begin{tabular}{|c|c|c|c|}
\hline $\begin{array}{l}\text { Mass spectral peaks } \\
\text { corresponding to cleavage* }\end{array}$ & $\begin{array}{l}a m / e \\
b \mathrm{~m} / \mathrm{e}\end{array}$ & $\begin{array}{l}270 \\
290\end{array}$ & $\begin{array}{l}298 \\
327\end{array}$ \\
\hline Branch in 2-position* & & $\mathrm{C}_{14} \mathrm{H}_{29}$ & $\mathrm{C}_{16} \mathrm{H}_{83}$ \\
\hline Straight-chain ester* & & $\mathrm{C}_{16}$ & $\mathrm{C}_{18}$ \\
\hline $\begin{array}{l}\text { Strain } \\
\quad \text { G. bronchialis }\end{array}$ & $\begin{array}{l}\text { N654 } \\
\text { N66I }\end{array}$ & $\begin{array}{c}++ \\
+\end{array}$ & $\begin{array}{l}+++ \\
+++\end{array}$ \\
\hline G. rubra & $\begin{array}{l}\text { N655 } \\
\text { N657 } \\
\text { N658 }\end{array}$ & $\begin{array}{l}++ \\
++ \\
+t\end{array}$ & $\begin{array}{l}+++ \\
+++ \\
+++\end{array}$ \\
\hline G. terrae & $\begin{array}{l}\text { N656 } \\
\text { N659 } \\
\text { N662 }\end{array}$ & $\begin{array}{l}++ \\
++ \\
++\end{array}$ & $\begin{array}{l}+++ \\
+++ \\
+++\end{array}$ \\
\hline N. kirovani & N647 & +++ & + \\
\hline
\end{tabular}

* Explanation of assignment of peaks is given in the accompanying paper (Alshamaony et al. 1976).

The anhydromycolic esters of Gordona and Nocardia kirovani strains consist of homologous series containing from one to four double bonds with the main components of the parent mycolic acids centring on $\mathrm{C}_{56}, \mathrm{C}_{58}, \mathrm{C}_{62}$ or $\mathrm{C}_{64}$, with a total range from $\mathrm{C}_{52}$ to $\mathrm{C}_{66}$ (Table 3). Although the range of chain lengths, and the major components, of the mycolic esters show a degree of variation there is a reasonably consistent pattern within each species. The two strains of Gordona bronchialis produced mycolates from $\mathrm{C}_{54}$ to $\mathrm{C}_{66}$ (major components $\mathrm{C}_{62}$ to $\mathrm{C}_{64}$ ). Nocardia kirovani contained free mycolic acids having a range $\left(\mathrm{C}_{59}\right.$ to $\left.\mathrm{C}_{65}\right)$ similar to that $\left(\mathrm{C}_{58}\right.$ to $\left.\mathrm{C}_{66}\right)$ recorded by Maurice et al. (1971). A second group was formed by the mycolates from the $G$. rubra and $G$. terrae strains, ranging from $C_{52}$ to $C_{62}$. This suggests that the taxa examined are characterized by a particular type of mycolic acid with a chain length centred around $\mathrm{C}_{60}$. The apparent affinity between $N$. kirovani and the gordonae should be examined in more detail.

The free molecular weights of the mycolic acids from G. bronchialis, G. rubra and G. terrae are significantly higher than those from nocardiae and rhodochrous strains, but in general are very much lower than those from mycobacteria. The free mycolic acids from the gordonae range from $\mathrm{C}_{52}$ to $\mathrm{C}_{66}$, thereby forming molecular species which can be distinguished from nocardomycolic acids $\left(C_{46}\right.$ to $\left.C_{58}\right)$, mycolic acids sensu stricto $\left(C_{70}\right.$ to $\left.C_{90}\right)$ and those which characterize many rhodochrous strains $\left(\mathrm{C}_{34}\right.$ to $\mathrm{C}_{50}$ ) (Alshamaony et al. 1976). These results support the view that the gordonae are more closely related to Nocardia than to Mycobacterium but can be distinguished from each of these genera (Tsukamura, 1971). It also seems likely that structural analysis of methyl mycolate moieties may provide an additional way of distinguishing between gordonae and many rhodochrous strains.

A 14 or 16 carbon ester is the major product detected by mass spectrometry of mycolates from nocardiae and rhodochrous strains (Alshamaony et al. 1976), whereas the major esters released on pyrolysis of methyl mycolates of mycobacteria are usually in the range $\mathrm{C}_{22}$ to $\mathrm{C}_{26}$ (Lechevalier et al. 1971, 1973). However, the major product on mass spectrometry of Gordona mycolates was an 18 carbon ester, which also suggests that gordonae are intermediate between nocardiae and mycobacteria. 
Table 3. Peaks in the mass spectra of methyl mycolates of gordonae and $N$. kirovani corresponding to anhydromycolates

The main component of each series is denoted by +++ , any component greater than $50 \%$ of the main peak by ++ and all other significant components by + .

No. of carbons in parent mycolic

acid

No. of G. bronchialis double $\overbrace{\mathrm{N} 654} \mathrm{N66 \textrm {I }}$

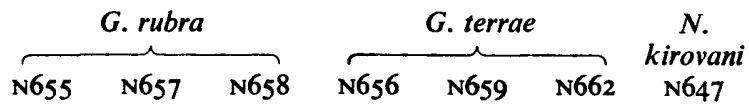

$\mathrm{C}_{52}$

$m e$

4

$$
\begin{aligned}
& \begin{array}{ll}
. & \cdot \\
. & \cdot \\
. & \cdot \\
. & \cdot \\
. & \cdot \\
. & .
\end{array} \\
& \begin{array}{ccc} 
& + & + \\
+ & + & + \\
++ & + & + \\
+ & . & +
\end{array} \\
& +
\end{aligned}
$$$$
\begin{array}{lll}
+ & & + \\
+ & + & + \\
+ & + & +
\end{array}
$$$$
\mathrm{C}_{53} \quad 780
$$$$
782
$$$$
\mathrm{C}_{54} \quad 792
$$$$
\begin{array}{r}
792 \\
794
\end{array}
$$$$
796
$$$$
798
$$

$\mathrm{C}_{55}$

$\mathrm{C}_{5}$

$\mathrm{C}_{58}$

$\mathrm{C}_{50}$

$$
\begin{array}{cccccc}
+ & ++ & ++ & ++ & . & + \\
++ & ++ & ++ & ++ & + & + \\
+ & . & \cdot & + & + & + \\
++ & . & . & + & + & \text {. }
\end{array}
$$

$$
\begin{array}{ccc}
++ & ++ & ++ \\
+ & + & + \\
+ & + & + \\
+ & + & + \\
++ & ++ & ++ \\
++ & ++ & ++
\end{array}
$$$$
\begin{array}{cccc}
+ & + & + & + \\
++ & ++ & ++ & ++
\end{array}
$$$$
+
$$ 
Analysis of the mycolic acid moieties separates strains of Gordona (Tsukamura, I97I) from those in the 'rhodochrous' complex (Goodfellow, 197I) but the sharp distinction between these taxa is probably more apparent than real. Thus, three rhodochrous strains (ATCC4273, ATCCI 3808 and N3I), classified as Gordona rhodochroa (Tsukamura, 1973), produce anhydromycolic esters which consist of homologous series containing zero to two double bonds and mycolates ranging from $\mathrm{C}_{38}$ to $\mathrm{C}_{48}$ (major component $\mathrm{C}_{44}$ ) (Alshamaony et al. 1976). Although it is difficult to compare phena from different numerical taxonomic studies it is apparent that $G$. rhodochroa (Tsukamura, 1973, 1974) is substantially the same taxon as Nocardia rubra (Bradley, 197I), and the rhodochrous subclusters $14 \mathrm{C}$ (Goodfellow, 197I) and $\mathrm{i} a$ (Goodfellow et al. 1974). Again, further centres of variation have been discovered in the 'rhodochrous' complex (Goodfellow et al. 1974) and there is some evidence that one of the new phena contains strains with mycolic acids similar to those of true nocardiae (Alshamaony et al. 1976). It seems probable, therefore, that mycolic acids with different chain lengths will be characteristic of different Gordona and rhodochrous subclusters. If the 'rhodochrous' complex and the proposed genus Gordona were merged to form a single genus, the structure of the mycolic acids might be of value in differentiation at the subgeneric level.

Thanks are due to Ms G. Alderson for maintaining cultures and preparing cells, and to P. Kelly for mass spectrometry. One of us (L.A.) acknowledges a grant from the Calouste Gulbenkian Foundation and support from the University of Mosul, Iraq, and M.G. is grateful for help from the Medical Research Council (grant G970/1 I2/73).

\section{REFERENCES}

Alshamaony, L., Goodfellow, M. \& Minnikin, D. E. (1976). Free mycolic acids in the classification of Nocardia and the 'rhodochrous' complex. Journal of General Microbiology 92, 188-199.

BradLEY, S. G. (197I). Criteria for definition of Mycobacterium, Nocardia and the rhodochrous complex. Advancing Frontiers of Plant Sciences 28, 349-362.

Cross, T. \& Goodfellow, M. (1973). Taxonomy and classification of the actinomycetes. In Actinomycetales: Characteristics and Practical Importance, pp. I I-1 12. Edited by G. Sykes and F. A. Skinner. London: Academic Press.

Goodfellow, M. (1971). Numerical taxonomy of some nocardioform bacteria. Journal of General Microbiology 69, 33-80.

Goodfellow, M., Lind, A., Mordarska, H., Pattyn, S. \& Tsukamura, M. (1974). A co-operative numerical analysis of cultures considered to belong to the 'rhodochrous' complex. Journal of General Microbiology 85, 291-302.

GoOdfellow, M. \& ORChARD, V. A. (1974). Antibiotic sensitivity of some nocardioform bacteria and its value as a criterion for taxonomy. Journal of General Microbiology 83, 375-387.

Lechevalier, M. P., Horan, A. C. \& Lechevalier, H. A. (1971). Lipid composition in the classification of nocardiae and mycobacteria. Journal of Bacteriology 105, 313-318.

Lechevalier, M. P., Lechevalier, H. \& Horan, A. C. (1973). Chemical characteristics and classification of nocardiae. Canadian Journal of Microbiology 19, 965-972.

Maurice, M. T., Vacheron, M. J. \& MiCheL, G. (197I). Isolement d'acides nocardiques de plusieurs espèces de Nocardia. Chemistry and Physics of Lipids 7, 9-18.

Minnikin, D. E., PAtel, P. V. \& Goodfellow, M. (1974). Mycolicacids of representativestrains of Nocardia and the 'rhodochrous' complex. FEBS Letters 39, 322-324.

Mordarska, H., Mordarski, M. \& Goodfellow, M. (1972). Chemotaxonomic characters and classification of some nocardioform bacteria. Journal of General Microbiology 7x, 77-86.

Tsukamura, M. (1971). Proposal of a new genus, Gordona, for slightly acid-fast organisms occurring in sputa of patients with pulmonary disease and in soil. Journal of General Microbiology 66, I5-26.

TsukAMURA, M. (1973). A taxonomic study of strains received as 'Mycobacterium' rhodochrous. Japanese Journal of Microbiology 17, 189-197.

TsukamuRA, M. (1974). A further numerical taxonomic study of the rhodochrous group. Japanese Journal of Microbiology 18, 37-44. 